\title{
Comparative analysis of plant growth risks insurance in the Eurasian Economic Union countries
}

\author{
Tatyiana A. Verezubova ${ }^{1}$, Kirill A. Zhichkin ${ }^{2, *}$, Assem M. Mukhitbekova ${ }^{3}$, Anatoliy A. Penkin ${ }^{2}$, and Lyudmila N. \\ Zhichkina $^{2}$ \\ ${ }^{1}$ Belarusian State Economic University, Minsk, 220070, The Republic of Belarus \\ ${ }^{2}$ Samara State Agrarian Unversity, Kinel, 446442, Russia \\ ${ }^{3}$ S. Seifullin Kazakh Agrotechnical University, Nur-Sultan, 010011, The Republic of Kazakhstan
}

\begin{abstract}
The article presents the results of a comparative analysis of the procedure for conducting compulsory insurance of crops in three states of the Eurasian Economic Union - the Russian Federation, the Republic of Belarus and the Republic of Kazakhstan. The authors analyzed the main conditions for its implementation, the differences in the regulatory framework for the provision of state support, the dynamics of key indicators of development of this type of insurance, revealed the reasons for their changes. The ways of improving the state support for crop insurance in the EAEU countries are proposed.
\end{abstract}

\section{Introduction}

Agricultural production is the most vulnerable area of business. Its implementation carries significant risks. The output of ready agricultural products is influenced not only by the volume of financial investments and labor costs, but also by constant changes in natural and climatic conditions, seasonality of production, manmade disasters, a long cycle of ripening and storage of agricultural crops, etc. In this regard, conscious risk management is important for the implementation of the main tasks of enterprises of the agro-industrial complex [1-3]. As many scientists note, risk management includes an assessment of its degree, the process of implementing specific events that help minimize the negative impact of external and internal factors of the external and internal environment, bringing different losses [4-6]. In this case, the importance of not only an accurate assessment of the degree of risk increases, but also the search for minimizing its negative consequences. The most traditional methods of covering risk losses in the past and present time include insurance of the process of growing crops, which is one of the effective mechanisms for financial protection of agricultural producers [7-10]. The growth of insurance operations is expected in Eurasian Economic Union Countries (hereinafter - EAEUC) that could reduce the risk in agriculture, thereby reducing the negative consequences of the occurrence of adverse natural events as well as price fluctuations in the market.

\section{Materials and methods}

At present, the single agricultural insurance market of EAEU countries has just started to grow. Its development is negatively affected by the high cost of insurance services associated with the presence of significant risks in agriculture as well as the insufficiently active policy of promoting these operations by insurance companies and EAEU member states, relatively low level of information base of agricultural producers.

A project for the formation of a single insurance market is being developed by the decision of the Eurasian Congress of insurance companies across Eurasian Economic Union countries. To achieve this goal, organizational, managerial and economic prerequisites must be established: the harmonization of national legislation has been gradually completed and the basic requirements for insurance companies have been defined.

541 insurance companies operated across EAEU countries in 2012. Their number significantly had declined by 1.01.2018 and comprised just over 300 policy holders [11]. They offer personal and property insurance, liability insurance and a range of special insurance services. (Table 1).

The integration of insurance markets began in 2005 from the establishment of Interstate Coordination Council of Heads of Insurance Supervision States - CIS participants, by the decision of which the costs incurred in the production of crop products must be insured without fail. However, the mechanism of providing State Support across CIS countries has been different and defined in separate periods of time. In Russia, the insurance premium in the amount of $50 \%$ is reimbursed from the state budget, $95 \%$ in Belarus, and in Kazakhstan the state compensates insurance companies for the paid insurance indemnities in the amount of $50 \%$. There are other conditions for this type of insurance.

\footnotetext{
* Corresponding author: zskirill@ mail.ru
} 
Table 1. Number of Insurance Companies in EAEUC, 2012-2017, units

\begin{tabular}{|c|c|c|c|c|c|c|}
\hline \multirow{2}{*}{ Country } & \multicolumn{7}{|c|}{ Years } \\
\cline { 2 - 7 } & $\mathbf{2 0 1 2}$ & $\mathbf{2 0 1 3}$ & $\mathbf{2 0 1 4}$ & $\mathbf{2 0 1 5}$ & $\mathbf{2 0 1 6}$ & $\mathbf{2 0 1 7}$ \\
\hline Armenia & 7 & 8 & 7 & 7 & 7 & 7 \\
\hline Belarus & 25 & 25 & 24 & 24 & 23 & 18 \\
\hline Kazakhstan & 35 & 34 & 34 & 33 & 32 & 32 \\
\hline Kyrgyzstan & 16 & 18 & 17 & 17 & 19 & 18 \\
\hline Russia & 458 & 420 & 404 & 334 & 256 & 226 \\
\hline CU and EEA & 541 & 505 & 486 & 415 & 337 & 301 \\
\hline
\end{tabular}

\section{Results and discussion}

In the Russian Federation, since 1991, agricultural insurance in crop production with the state participation is voluntary. In accordance with the Law of the RSFSR "On the social development of a village" for Soviet farms, collective farms, farmers, peasant (farmer) farms and other agricultural enterprises of Russia, compulsory agricultural insurance was replaced by voluntary including sowing crops, trees (bushes), fruit and berries and other long-term trees and shrubs [12].

Crop insurance was sporadic due to the severe turbulence of the economic situation before 2003, in the framework of which, due to unfavorable pricing conditions, farmers were forced to finance technological issues immediately. Active promotion of agricultural insurance by means of state support commenced in 2003. Initial conditions were very favorable.

For example, across Samara Region in 2003-2006, as part of crop insurance by means of State Support from the Federal Budget, $50 \%$ was compensated from insurance premiums, $30 \%$ - from Regional Budget and $20 \%$ was paid by an agricultural enterprise. The terms and conditions have been changed since 2007 -

Table 2. The main parameters of the crop insurance system by means of the State Support in the Russian Federation, 20122018 [13]

\begin{tabular}{|c|c|c|c|c|c|c|}
\hline Year & $\begin{array}{c}\text { Number of } \\
\text { Concluded } \\
\text { Contracts, } \\
\text { pieces }\end{array}$ & $\begin{array}{c}\text { Insurance } \\
\text { sum, mln } \\
\text { rubles }\end{array}$ & $\begin{array}{c}\text { Insurance } \\
\text { Premium, } \\
\text { mln rubles }\end{array}$ & $\begin{array}{c}\text { Subsidies, } \\
\text { mIn rubles }\end{array}$ & $\begin{array}{c}\text { Reimbursement, } \\
\text { mIn rubles }\end{array}$ & $\begin{array}{c}\text { Unprofitable } \\
\text { insurance, \% }\end{array}$ \\
\hline 2012 & 7887 & 191703.0 & 10728.8 & 4390.3 & 4971.4 & 32.9 \\
\hline 2013 & 7734 & 232942.6 & 12078.5 & 4166.8 & 3507.8 & 21.6 \\
\hline 2014 & 8185 & 291136.4 & 14625.8 & 5042.2 & 2611.3 & 13.3 \\
\hline 2015 & 2487 & 185237.0 & 6514.2 & 1675.7 & 897.3 & 11.0 \\
\hline 2016 & 1595 & 139419.5 & 4368.5 & 2270.0 & 1964.3 & 29.6 \\
\hline 2017 & 494 & 44778.7 & 1343.7 & 508.4 & 1003.8 & 54.2 \\
\hline 2018 & 452 & 24361.6 & 982.2 & 438.7 & 359.7 & 25.3 \\
\hline
\end{tabular}

As can be seen from Table 2, the state-backed insurance market has actively responded to changes in legislation, which was accompanied by an increase in the number of contracts concluded and the amount of insurance premium.

However, a long period with relatively favorable climatic conditions, and as a result, a low ratio of reimbursement and funds spent led to a massive rejection of the use of crop insurance by means of the state support. If $18.5 \%$ of all the acreage of Russia was insured in 2012, it comprised only $5.0 \%$ in 2016 . At the same time, a wider spread of crop insurance without the consolidated budget compensated just $50 \%$ of the premium. The following change of the form of the state participation in crop insurance refers to 2011, Federal Law № 260-FL «Upon the State Support in the field of agricultural insurance and amendments in the Federal Law «Upon the development of Agriculture» was adopted. In it, in particular, the form of subsidies was changed. If before that, the agricultural company paid $100 \%$ of the insurance premium at the time of entering into the insurance contract and only subsequently received appropriate compensation from the state budget, now, in accordance with Paragraph 3. Art. 3 of this Law - the subsidy is transferred "... to the insurer's current account in the amount of $50 \%$ of the accrued insurance premium on the basis of the application of an agricultural producer".

Additionally, a policyholder was enabled to approach more flexibly to the formation of the insurance premium amount due to the use of the unconditional franchise in the range from 0 to $30 \%$ (previously, its value was fixed at $20 \%$ ) [12].

As a result of changes in approaches to the state support, significant fluctuations in insurance results can be noted in the Russian Federation (Table 2). state support can be noted. At a lower cost for a policyholder (in 2016, in accordance with «Federal Agency of the State Support AIC (AgroIndustrial Complex)», the average tariff accounted for $1.2 \%$ against $5.47 \%$ by means of the state support, and the level of payments - 262.7\%) [12].

These data indicate that the crop insurance method by means of the state support, both in determining insurance tariffs, and in optimizing the determination of the parameters of the insurance system requires further improvement.

In Belarus, on compulsory insurance by means of the state support for the crop harvests, livestock and poultry 
(hereinafter - CISSCHLP), a policyholder himself/herself pays only $5 \%$ of the insurance premium, and $95 \%$ is financed from the state budget. The only policyholder for this type of insurance is the state Company Belgosstrakh, which accumulates half of the insurance premiums in the Belarusian insurance market.
Each year, the Decree of the President of the Republic of Belarus determines the crops that are subject to compulsory insurance and the percentage of compensatory damages. Information about these conditions are presented in table 3 .

Table 3. Insured Agricultural crops and the percentage of compensatory damages under CISSCHLP in the Republic of Belarus, 2008-2019

\begin{tabular}{|c|l|c|}
\hline Year & \multicolumn{1}{|c|}{ Agricultural crops accepted for insurance } & $\begin{array}{c}\text { Compensation of damages or costs } \\
\text { on oversowing, \% }\end{array}$ \\
\hline 2008 & Winter wheat, winter triticale, spring wheat, barley & 50 \\
\hline 2009 & Winter wheat, winter triticale, spring wheat & 70 \\
\hline 2010 & Winter wheat, winter triticale, spring wheat & 100 \\
\hline 2011 & Winter wheat, winter triticale, winter rape, spring wheat & 50 \\
\hline 2012 & Winter wheat, winter triticale, winter rape, spring wheat & 50 \\
\hline 2013 & Winter wheat, winter triticale, winter rape, spring wheat, flax fiber & 50 \\
\hline 2014 & Winter wheat, winter triticale, winter rape, spring wheat, flax fiber & 50 \\
\hline 2015 & Winter wheat, winter triticale, winter rape, spring wheat, flax fiber & 50 \\
\hline 2016 & Winter wheat, winter triticale, winter rape, spring wheat, flax fiber & 17 \\
\hline 2017 & Winter rape, flax fiber & Spring- 17, Winter- 50 \\
\hline 2018 & Winter rape, flax fiber & Spring- 30, Winter- 17 \\
\hline 2019 & Winter rape, flax fiber & \\
\hline
\end{tabular}

As can be seen from table 3, the list of crops insured and the percentage of compensatory damages for 11 years of operation of CISSCHLP constantly changed and by 2017 had reduced up to two crops (winter rape and flax fiber). The percentage of the compensatory damage sharply dropped (up to $17 \%$ ).
Insurance rates are also high upon CISSHCLP. They differ in different regions of the Republic of Belarus, since they take into account their different climatic conditions and statistics of occurrence of insured events in previous years (Table 4).

Table 4. Insurance Rates upon CISSCHLP, 2019 [14]

\begin{tabular}{|c|c|c|c|c|c|c|}
\hline $\begin{array}{c}\text { Name of } \\
\text { agricultural } \\
\text { crops }\end{array}$ & \multicolumn{7}{|c|}{ Insuarnce Rate, \% from insurance sum } \\
\cline { 2 - 7 } & $\begin{array}{c}\text { Brest } \\
\text { Region }\end{array}$ & $\begin{array}{c}\text { Vitebsk } \\
\text { Region }\end{array}$ & $\begin{array}{c}\text { Gomel } \\
\text { Region }\end{array}$ & $\begin{array}{c}\text { Grodnen } \\
\text { Region }\end{array}$ & $\begin{array}{c}\text { Minsk Region } \\
\text { and Minsk city }\end{array}$ & $\begin{array}{c}\text { Mogilev } \\
\text { Region }\end{array}$ \\
\hline Winter Rape & 8.64 & 25.36 & 18.62 & 6.03 & 10.47 & 20.45 \\
\hline Flax Fiber & 2.53 & 2.94 & 1.32 & 0.75 & 1.87 & 4.02 \\
\hline
\end{tabular}

Insurance rates upon the insurance of crops have been significantly increased compared to the previous 2018 and established in 2019 upon winter rape in the range between 6 and $25 \%$ (from 4 up to $17 \%$ in 2018) and flax fiber - from 0.7 up to $4.02 \%$ (from 0.5 up to $2.5 \%)$.

Such high rates for agricultural producers would be hard to pay without the State Support in the form of 95 per cent coverage from the State Budget of the the Republic of Belarus.

However, they also do not allow Belgosstrakh to carry out this type of insurance profitably in all years. The leveling of risks in this segment often occurs at the expense of other insurance products, since the accumulated special insurance reserve for this type of insurance is almost completely used.

Therefore, the insurance coverage over the past 10 years has decreased significantly. One of the reasons is the high unprofitability of this compulsory type of insurance (Table 5).

The dynamics of insurance premiums for 2008-2018 differs from the uneven growth of their income. $95 \%$ of them comprised the budget resources and only $5 \%$ was paid by agricultural companies. Mobilized insurance premiums were used to cover unexpected crop losses, including reseeding.

The volume of payments for seperate years depended on the actual size of the damage to the Republic's agriculture. In 2018, winter rape crops were again affected by freezing, and flax fibre by a spring drought. Insurance payments for the first half of 2018 were closer to the received contributions.

However, some restoration of the insurance reserve on the results of 2017 allowed one to plan an increase in the percentage of compensatory damages from $17 \%$ to $30 \%$ in 2019.

Thus, in the Republic of Belarus, the state annually applies compulsory insurance to cover damage to agriculture and ensures its development to meet the food needs of the population of the Republic.

In Kazakhstan, compulsory crop insurance was introduced in 2004. Over the years of the insurance program, no fundamental changes have occurred, except for granting the right to insure their risks to agricultural producers by uniting into mutual insurance societies (hereinafter - MIS).

Initially, in 2004, 7 insurance companies dealt with agricultural insurance (hereinafter - IC). 
Table 5. The Results of compulsory insurance of crops in the Republic of Belarus, 2008-2018 CISSHCLP [15]

\begin{tabular}{|c|c|c|c|c|c|c|}
\hline Years & $\begin{array}{c}\text { Number } \\
\text { of } \\
\text { Contracts }\end{array}$ & $\begin{array}{c}\text { Insurance } \\
\text { premiums, } \\
\text { paid by } \\
\text { policyholders } \\
(\mathbf{5 \%}) \text {, thousand } \\
\text { rubles }\end{array}$ & $\begin{array}{c}\text { Insurance } \\
\text { premiums, } \\
\text { paid from the } \\
\text { budget } \\
(95 \%), \\
\text { thousand } \\
\text { rubles }\end{array}$ & $\begin{array}{l}\text { Total paid } \\
\text { insurance } \\
\text { premiums, } \\
\text { thousand } \\
\text { rubles }\end{array}$ & $\begin{array}{c}\text { Paid } \\
\text { insurance } \\
\text { compensa } \\
\text { tion, } \\
\text { thousand } \\
\text { rubles }\end{array}$ & $\begin{array}{l}\text { Unpro- } \\
\text { fitabi- } \\
\text { lity, \% }\end{array}$ \\
\hline 2008 & 4164 & 578.95 & 6057.73 & 6636.68 & 904.4 & 13.6 \\
\hline 2009 & 2500 & 400.49 & 2135.57 & 2536.06 & 2164.0 & 85.3 \\
\hline 2010 & 2562 & 109.07 & 964.15 & 1073.22 & 30271.0 & 2821.2 \\
\hline 2011 & 4517 & 457.2 & 3031.54 & 3488.74 & 96326.1 & 2761.1 \\
\hline 2012 & 4608 & 1403.22 & 9679.21 & 11082.43 & 2963.38 & 26.7 \\
\hline 2013 & 4113 & 2158.98 & 14451.34 & 16610.32 & 15647.46 & 94.2 \\
\hline 2014 & 4191 & 1808.52 & 18875.26 & 20683.78 & 9749.2 & 47.13 \\
\hline 2015 & 4881 & 1559.87 & 24044.67 & 25604.54 & 41789.79 & 163.2 \\
\hline 2016 & 3132 & 1678.4 & 33629.3 & 35307.7 & 37558.4 & 106.4 \\
\hline 2017 & 4250 & 1012.53 & 29423.79 & 30436.32 & 20617.63 & 67.7 \\
\hline 2018 & 1222 & 1025.20 & 19478.80 & 20504.00 & 5814.89 & 28.4 \\
\hline
\end{tabular}

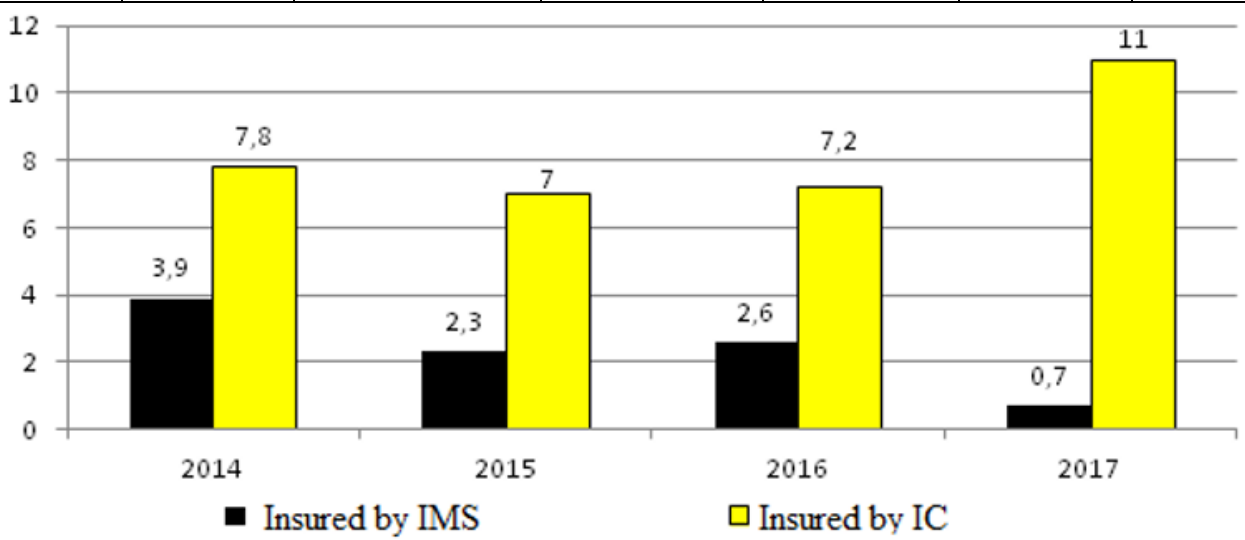

Fig. 1. Dynamics of insured crops in Kazakhstan for 2014 - 2017, million hectares [16]

However, due to the significant risk and, consequently, the unprofitability of this type of insurance, currently, in the compulsory insurance market of crops in Kazakhstan, there are just only two IC: established by the state in 1995 JSC «Daughter Insurance Company of the People's Bank of Kazakhstan «Khalyk-Kazinstrakh» and JSC "Grain Insurance Company" established in 2003 and specialized in providing insurance protection for agricultural companies.

They provide not only insurance in the field of crop production, but also many other types of insurance, which cover losses incurred in crop insurance. The work of the MIS is different in that the next insurance premiums can be reduced by the general meeting of the company's members, if at the end of the accounting period the company had no arrears in insurance payments, taxes and other obligatory payments to the budget. The crop areas insured by them for 2014-2017 are presented in Figure 1.

The area of insured MIS crops during the analyzed period decreased significantly. If 3.9 million hectares (33 $\%)$ were insured in 2014, then just 0.7 million hectares $(6.2 \%)$ were insured in 2017 . Then IC extended insured fields from 7.8 million hectares in 2014 up to 11.0 million hectares in 2017.
The Law of the Republic of Kazakhstan "On Insurance" establishes minimum and maximum rates for groups of cultures. The size of insurance rates for compulsory insurance in the crop industry of Kazakhstan are differentiated by types of crops and by regions (Table 6).

As a rule, in practice, the amount of insurance premiums due to the low solvency of agricultural producers is calculated at the minimum insurance rate. This does not allow to form a sufficient reserve for insurance payments, which adversely affects the financial stability of insurance companies, especially when insurance events occur.

Another problem in Kazakhstan is the lack of readiness of insurance companies to organize insurance properly in the agricultural sector. Representatives of policy holders do not have time to inspect crops on time, assess the size of losses, and mobilize resources for their compensation.

In recent years, insurance companies have suffered significant financial losses in compulsory insurance of crops and therefore give up their business. The main indicators of insurance companies of Kazakhstan on compulsory insurance of crop production are presented in Figure 2. 
Table 6. Minimum and maximum sizes of insurance rates in Kazakhstan for compulsory insurance in the crop industry [17]

\begin{tabular}{|c|c|c|c|}
\hline \multirow[t]{2}{*}{ № } & \multirow[t]{2}{*}{ Name of Regions } & \multicolumn{2}{|c|}{ Insurance rates, \% } \\
\hline & & Minimum & Maximum \\
\hline 1. & \multicolumn{3}{|l|}{ Grain Crops } \\
\hline 1.1. & Akmola, Almaty, East Kazakhstan, Zhambyl, Kostanay, North Kazakhstan & 1.78 & 3.48 \\
\hline 1.2 . & Karaganda, Kyzylorda, Pavlodar, South Kazakhstan & 3.17 & 5.83 \\
\hline 1.3 . & Aktobe, West Kazakhstan & 5.21 & 9.15 \\
\hline \multirow[t]{2}{*}{2.} & \multicolumn{3}{|l|}{ Oilseeds } \\
\hline & In all regions & 2.01 & 3.44 \\
\hline 3. & \multicolumn{3}{|l|}{ Sugar Beet } \\
\hline & In all regions & 5.76 & 8.39 \\
\hline 4. & \multicolumn{3}{|l|}{ Cotton } \\
\hline & In all regions & 0.92 & 1.33 \\
\hline
\end{tabular}

As can be seen, the value of mobilized insurance premiums in Kazakhstan over the past 10 years has fluctuated smoothly and almost doubled by 2018 compared to 2009. As for insurance payments, in certain years, the payments significantly exceeded the premiums accumulated for this type of insurance. This was due to severe drought in the Republic in 2008, 2010, 2012 and 2014 which led to the the loss of crops and, accordingly, to the spasmodic growth of insurance payments.

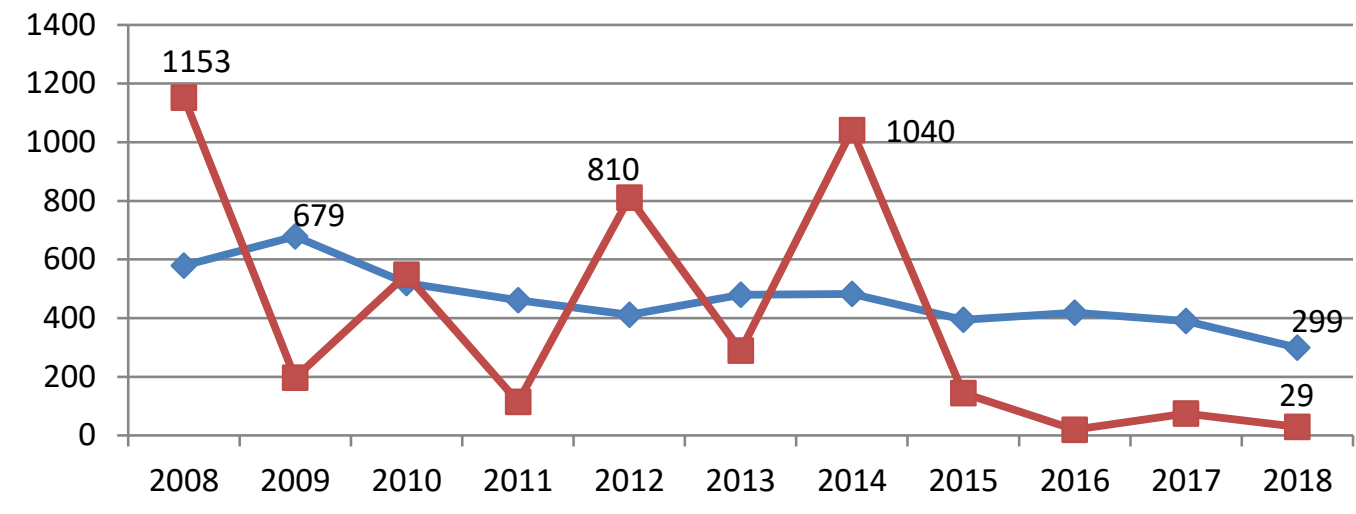

Fig. 2. The main indicators of insurance of crop production in Kazakhstan, 2008-2018 (mln tenge)

In more favorable 2015-2018 years insurance premiums exceeded payouts. The average loss ratio for this type of insurance for the analised period comprised $89 \%$, however, a measure of the spread of data around the average value reflects a significant variance in a number of payments, the standard deviation comprised 419 mln tenge.

The State Support of compulsory insurance in crop production in the Republic of Kazakhstan in the analyzed period was carried out by allocating budget funds to the authorized state body in the field of crop production for reimbursement of $50 \%$ of insurance payments to IC and MIS for insured events resulting from adverse natural phenomena, as well as to pay for agent services.

The analysis of the national insurance market of Kazakhstan allows us to conclude that crop insurance occupies an insignificant place in the total volume of compulsory insurance: from 1 to $1.7 \%$ until 2013, and in the last four years of the analyzed period, its share decreased even more in 2017 accounted for only $0.3 \%$ of the total income of the insurance sector in Kazakhstan. These indicators imply the drawbacks in the organization of this type of insurance, which affects the weakness of the financial protection of the industry.

\section{Conclusion}

Meanwhile, as the world practice confirms, insurance acquires paramount importance in enhancing the financial protection of agricultural producers, which is subject to significant losses due to the influence of anomalous natural and climatic conditions. These problems are sharpened by the integration of many countries into EAEU, uniting a large population. They need to expand the food program, largely dependent on the state of their agriculture in the common territory of the community.

One of the active tools of its development can be compulsory and voluntary insurance of crop harvests, mitigating the inevitable losses from natural and climatic phenomena.

The solution to this problem is complicated not only by significant natural differences of the member - states of EAEU, but a differentiated level of a comapny and state of agricultural insurance in different countries, as well as the degree of economic development and other national characteristics. In this regard, at the initial stage of the formation of a single insurance market for EAEU, the unification of the rules of operation of the single insurance market as well as the method of calculating its 
key indicators, becomes possible only after the proper development of national insurance markets and their convergence, facilitation of modernization and enhancement of the financial protection of all sectors of the economy and population from unforeseen losses. As one of the important insurance objects that are actively influencing the reduction of the riskiness of agriculture and its development, insurance of crop harvests should be compulsory and voluntary.

\section{Acknowlegement}

This article was prepared with the support of the Belarusian Republican Foundation for Fundamental Research.

\section{References}

1. J. Yu, D.A. Sumner, Agricultural Economics (United Kingdom) 49(4), 533-545 (2018)

2. S. Shaik, K.H. Coble, T.O. Knight, A.E. Baquet, G.F. Patrick, J. Agr. Appl. Econ. 40(3), 757-766 (2008)

3. V.H. Smith, J.W. Glauber, Applied Economic Perspectives and Policy 34(3), 363-390 (2012)

4. T.A. Verezubova, T.V. Sorokina, Insurance in the system of financial services in Russia: place, issues, transformation 1, 259-263 (Kostroma State University, Kostroma, 2017) (In Russ.)

5. N.V. Kirienko, I.A. Kazakevich, Bulletin of the Belarus State Economic University 3, 86-93 (2014) (In Russ.)

6. B.J. Barnett, J.R. Black, Y. Hu, J.R. Skees, J. of Agricultural and Resource Economics 30(2), 285$301(2005)$
7. K.H. Coble, B.J. Barnett, American J. of Agricultural Economics 95(2), 498-504 (2013)

8. C. Rosenzweig, J. Elliott, D. Deryng, A.C. Ruane, C. Müller, A. Arneth, K.J. Boote, J.W. Jones, Proc. of the National Academy of Sciences of the United States of America 111(9), 3268-3273 (2014)

9. M.J. Roberts, W. Schlenker, J. Eyer, American J. of Agricultural Economics 95(2), 236-243 (2013)

10. R.M. Rejesus, K.H. Coble, M.F. Miller, R. Boyles, B.K. Goodwin, T.O. Knight, J. of Agricultural and Resource Economics 40(2), 306-324 (2015)

11. Financial Organizations in Eurasian Economic Union. 2013-2017 Retrieved from: http://eec.eaeunion.org/ru/act/integr_i_makroec/dep _stat/fin_stat/statistical_publications/Documents/fin stat_3/finstat_3_2017.pdf (In Russ.)

12. T.A. Verezubova, K.A. Zhichkin, A.M. Mukhitbekova, Finance 10, 55-60 (2018) (In Russ.)

13. Central Bank of the Russian Federation Retrieved from: http://www.cbr.ru (In Russ.)

14. Report upon the state of the agricultural insurance market, executed by means of State Support in the Russian Federation in 2016 Retrieved from: http://fagps.ru/getfile/d5f79a4a5357e4665ef6a5cb1d 543295/9.pdf (In Russ.)

15. Belgosstrakh Retrieved from: http:// www.bgs.by (In Russ.)

16. National Bank of Kazakhstan Retrieved from: http://www.nationalbank.kz. (In Russ.)

17. B. Aimurzina, M. Kamenova, A. Omarova, A. Karipova, A. Khoich, J. of Environmental Management and Tourism 9(6), 1342-1350 (2018) 